Bull. Fac. Agric., Cairo Univ., 66:40- 53 (2015)

\title{
INFLUNCE OF WATER REGIMES AND WEED CONTROL TREATMENTS ON SESAME CROP
}

(Received:11.3.2015)

\author{
By \\ A.E.A. Ismail , F. Sh. Sedeck* and S. A. M. Ali** \\ Weed Central Laboratorey, *Field Crops Research Institute, \\ ** Soil and Water Research Institute, Agricultural Research Center, Giza, Egypt
}

\begin{abstract}
A field experiment was conducted at Shandaweel Research Station, Sohag Governorate during 2012 and 2013 seasons to investigate the influence of three water regimes at 100, 80 and $60 \%$ of field capacity, two sesame cultivars ( Shandaweel 3 and Sohag 2000 ) and six weed control treatments (Prometryn at rate of $375 \mathrm{~g}$ active ingredient (a. i) /fed., bentazon at rate of $240 \mathrm{~g}$ a. i /fed., prometryn and bentazon with one hand hoeing, hand hoeing twice and weedy check) on water relations and sesame productivity. A split-split plot design with three replications was used. The results showed that irrigating sesame at $60 \%$ of FC significantly reduced annual broad leaved, grassy and total weeds in both seasons compared to irrigation water at $100 \%$ of FC. While, irrigation at $100 \%$ of FC significantly increased growth and yields of sesame and its attributes compared to irrigation at $60 \%$ FC. Sohag - 2000 cultivar significantly inhibits growth of annual broad leaved, grassy and total weeds and increased plant height, number of branches and capsules /plant, capsule length, 1000- seed weight, seed yield and oil \%, compared with Shandaweel-3 cultivar. All weed control treatments significantly reduced the dry weight of annual broad leaved, grassy and total weeds in both seasons. Hand hoeing twice, bentazon followed by H.H. once, + prometryn follow by H.H. once, gave the highest reduction $\%$ in the total annual weeds and increased significantly plant height, the number of branches / plant, number of capsules /plant, capsule length, 1000 seed weight, seed yield /fad. and oil \%, compared to un-weeded treatment. Water consumptive use (CU) values were 2252.6, 2016.1, 1656.9, 2261.7, 2020.4 and $1654.2 \mathrm{~m}^{3} / \mathrm{fed}$ for 100,80 and $60 \%$ of FC treatment, respectively, in both seasons. The highest value of water use efficiency (WUE) was recorded by irrigation at $80 \%$ of FC. The highest CU and WUE were recorded by Sohag - 2000 cultivar, compared to Shandaweel-3 cultivar. Under the conditions of this experiment sowing Sohag- 2000 cultivar with using hand hoeing twice, bentazon followed by H.H. once, and prometryn followed by H.H. once and irrigation at $80 \%$ of FC can be recommended to obtain the highest oil and sesame yield/fed.
\end{abstract}

Key words: Prometryn, Bentazon, Water consumptive use, Water use efficiency, Hand hoeing.

\section{INTRODUCTION}

Seeds of sesame (Sesamum indicum, L.) are rich in both portien and oil. Egypt is suffering drastically from the shortage of edible oils. The gap between the production of vegetable oils and their consumption is more than 95\%. In Egypt, the total cultivated area of sesame is about 60,000 feddan giving 33,000 tons of seeds *Bulletin of the Agricultural statistics (2013).

The oil production can be increased horizontally by increasing the area of oil crops in new locations and/or vertically by increasing the total yield of seeds. This aim can be achieved by improving irrigation and weed control programs of high yielding cultivars. According to the report by the Ministry of Irrigation (1972), water use by sesame reached 1700, 2200 and 2300 $\mathrm{m}^{3} /$ feddan for Delta, Middle and Upper Egypt, respectively. Hong et al. (1985) indicated that drought stress during vegetative growth reduced seed yield of sesame from 8.5 to $4.3 \mathrm{t} \mathrm{ha}^{-1}$. Joshi (1985) indicated that sesame is very susceptible to both drought and water logging since it is slow in establishment. Ayasamy and Kulandiavelu (1992) found that seed yield increased by increasing soil moisture content through different stages of plant development. Kwan et al. (2007) found that drought stress decreased seed yield per plant but did not affect the weight of individual seed. Ucan et al. (2007) 
showed that increasing the number of irrigations, decreased sesame yield. Ahmed et al. (2010) showed that the highest water quantity $(750 \mathrm{~mm})$ significantly increased the number of capsules per plant, the number of seeds per capsule, 1000 seed weight, seed yield per plant and seed yield /ha, compared to the lowest water quantity (350 $\mathrm{mm}$ ). Kassab et al., (2012) revealed that the highest values of sesame growth parameters, seed and oil yields /fed. were gained by irrigating sesame plants with $100 \%$ of Etc followed by $75 \%$ of Etc in both seasons compared to $50 \%$ of Etc. Damdar et al., (2014) revealed that yield contributing characters and moisture studies were significantly higher with irrigation scheduling at 1.0 IW/CPE (Irrigation water amount/Cumulative pan evaporation) compared to irrigation scheduling at 0.4 IW/CPE.

In this concern, Basha (1998) showed that sesame varieties significantly differed in growth and yield attributes. Also, Basha and Awaad (2000) showed that B10 genotype surpassed Sharkia and Giza 32 cultivars in fruiting zone length, capsule length, seed and oil yields/fed, whereas the differences in number of branches and capsules/plant were in favor of Giza 32 variety. While, Sharkia cultivar gave the least values of plant height, fruiting zone length and capsule length. Abdel-Wahab et al. (2005) showed that Giza 32 variety significantly had longer fruiting zone and gave the higher number of capsules/plant, 1000-seed weight, seed yields and seed oil content over Toshky 1 cultivar. While, Abo-El-Wafa and Abdel-Latief (2006) showed that Toushky-1 and Giza 32-cultivars surpassed Shandaweel-3 in seed yield and yield attributes, while seeds of Giza 32 were more rich in oil content. Rehab and Fakkar (2007) reported that sowing Toshky-1 cultivar significantly decreased the dry weight of grassy, broad and total weeds/ $\mathrm{m}^{2}$ and increased plant height, fruiting zone length, capsule length, number of capsules/plant, seed yield/fed., 1000 -seed weight, oil \% in seeds compared to Shandawel-3 cultivar in both seasons. Hassanzadeh et al. (2009) studied the effect of water stress on yield and yield components of 27 sesame genotypes. He demonstrated that the numbers of capsules per plant and grain yield were significantly affected by irrigation and genotypes. Ahmed et al.(2010) showed that Khidir and Promo cultivars had insignificant effect on seed yield. Kassab et al. (2012) showed that Shandweel 3 sesame cultivars gave the highest plant height, the number of capsules/plant, and dry weight of capsules/plant.

Weed infestation is one of the major factors limiting the yield of sesame as its seedling growth which was slow during the first three to four weeks making it a poor competitor at earlier stages of crop growth (Bennett et al.,2003). During the seedling phase, monocotyledonous and dicotyledonous weeds suppress sesame's growth and finally affect the production per unit area to about 44 percent (Gurnha, 1974). Balyan (1993) and Singh et al.(1992) reported that weeds reduced yield up to $135 \%$ and there is need for a critical weed-free period up to 50 days after planting. Several herbicides provide excellent control of weeds with minimal to no damage to sesame. Also, in some cases, at the same location, the herbicides effectively control weeds and little sesame injury was noted in one year; however, the opposite may be true the following year. Rehab and Fakkar (2007) reported that all weed control treatments increased significantly seed yield /fed. Water use efficiency by weeds is one type of loss that contributes to the cost of weeds to agriculture. Kassab et al. (2012) found that the highest seed yield (kg/fed.) and WUE was obtained from irrigating Shandweel 3 sesame cultivar by $100 \%$ of Etc in two growing seasons.

The objectives of this investigation were to study the influence of different irrigation water regimes and some weed control treatments on the yield of two sesame cultivars.

\section{MATERIALS AND METHODS}

Two field experiments were conducted during 2012 and 2013 seasons at the farm of Shandaweel Research Station, Sohag Governorate, Egypt to determine the effect of three irrigation regimes and some weed control treatments on growth and yield of two sesame cultivars as well as water consumptive use and water use efficiency. Soil texture and soil moisture constants of the experimental site are presented in Table (1).

Experiment was laid out in a split- split-plot design with three replicates. Each experiment contains the following treatments: - 
Table (1): Soil texture, field capacity, available soil moisture, welting point and bulk density of the experimental site.

\begin{tabular}{|c|c|c|c|c|c|}
\hline $\begin{array}{l}\text { Soil depth } \\
\quad \text { (cm) }\end{array}$ & Soil texture & $\begin{array}{c}\text { Field capacity } \\
(\%)\end{array}$ & $\begin{array}{c}\text { Welting point } \\
(\%)\end{array}$ & $\begin{array}{c}\text { Available } \\
\text { soil moisture } \\
(\%)\end{array}$ & $\begin{array}{c}\text { Bulk density } \\
\quad\left(\mathrm{g} / \mathrm{cm}^{3}\right)\end{array}$ \\
\hline$\overline{0-15}$ & Clay loam & 27.60 & 15.50 & 12.1 & 1.34 \\
\hline $15-30$ & Clay loam & 28.00 & 14.10 & 13.9 & 1.36 \\
\hline $30-45$ & Clay & 12.20 & 7.20 & 5.0 & 1.56 \\
\hline $45-60$ & Clay & 15.10 & 6.40 & 8.7 & 1.57 \\
\hline
\end{tabular}

\subsection{Main plot (Water regimes)}

Irrigation treatments $\left(\mathrm{m}^{3} /\right.$ fed.) were $100 \% 80$ and $60 \%$ of field capacity. These irrigation treatments were 3754,3360 and $2761 \mathrm{~m}^{3} /$ fed., respectively, in 2012 season and 3762, 3363.5 and $2759 \mathrm{~m}^{3} /$ feddan in 2013 season.

1. Water relation for sesame .

2. Water consumptive use

It was estimated by using the soil sampling method and calculated according to the technique used and according to Israelsen and Hansen (1962).

$\mathrm{CU}=\mathrm{D} \times \mathrm{B}_{\mathrm{d}} \times(\mathrm{Q} 2-\mathrm{Q} 1) / 100$

Where:

$\mathrm{CU}=$ water consumptive use in the effective

root zone.

$\mathrm{D}=$ Soil layer depth.

$\mathrm{B}_{\mathrm{d}}=$ Soil bulk density.

$\mathrm{Q}_{1}=$ Soil moisture \%, before irrigation.

$\mathrm{Q}_{2}=$ Soil moisture \%, 48 hours after irrigation.

For soil moisture determination, soil samples were taken from each $15 \mathrm{~cm}$ depth up to $60 \mathrm{~cm}$ from the soil surface by a regular augur. The samples were weighed immediately and then oven dried to a constant weight at $105{ }^{\circ} \mathrm{C}$. Percentage of soil moisture at the four soil depths was calculated on oven dry weight basis. The amount of water consumed in each irrigation interval was obtained from the difference between soil content before the following irrigation and field capacity.

Actual irrigation water requirement .

The amounts of actual applied water were determined according to James (1988) using the following equitation:

$$
I=\frac{\left[\frac{\left(f_{c}-f_{m}\right)}{100}\right]}{I E} \times D_{r} \times L F
$$

I = total actual irrigation water applied $\mathrm{mm} /$ interval.

$\mathrm{f}_{\mathrm{c}}=$ soil moisture content at field capacity on volume basis.

$\mathrm{f}_{\mathrm{m}}=$ Volumetric soil moisture content before next irrigation $\mathrm{dr}=$ depth of soil layer .

$\mathrm{Lf}=$ leaching factor $10 \%$.

$\mathrm{IE}=$ irrigation system efficiency.

\subsection{Water use efficiency(WUE)}

Water use efficiency (WUE) values for the examined treatments were calculated according to the relation given by Jensen (1983):

WUE $=\quad$ Total seed yield

\subsubsection{Sub-plot (Cultivars):}

Shandaweel 3 unbranched stem and Sohag 2000 branched stem cultivars were used.

2.2.2. Weed control treatments (Sub-subplots):-

1. Prometryn 50\% SC [ 4- amino- 3, 5- chloro6- fluoro- 2 pyridyloxyaceticacid ] known commercially as (Gesagard) was applied at the rate of $375 \mathrm{~g}$ a.i/fed. as pre- emergence before sowing irrigation.

2. Bentazon $48 \%$ AS [3-Isopropyl-1H-2,1,3benzothiadiazin-4 (3H)- one 2,2-dioxide] known commercially as (Basagran) was applied at rate of $240 \mathrm{~g}$ a.i /fed. as post- emergence at 21days after sowing (DAS)

3. Prometryn at rate of $375 \mathrm{~g}$ a.i/fed. plus hand hoeing once after one month from herbicide application.

4. Bazagran at rate of $240 \mathrm{~g}$ a.i /fed. applied at 30 DAS plus hand hoeing once after 42 DAS from herbicide application.

5. Hand hoeing twice at 21 and 42 days after sowing.

6. Un-weeded check.

Knapsack sprayer was used with water volume of $200 / f e d$. The experimental basic unit area included 3 ridges each of $120 \mathrm{~cm}$ width and $5.0 \mathrm{~m}$ length occupying an area of $18.0 \mathrm{~m}^{2}$. The preceding winter crop was Egyptian clover (Trifolium alexandrinum L.) in both seasons. Seeds of sesame were sown in hills $10 \mathrm{~cm}$ a part on ridges of $120 \mathrm{~cm}$ spacing in June 5 and $10^{\text {th }}$ in the first and second seasons, respectively. Plants were thinned to secure only one plant per hill (10 $\mathrm{cm}$. space) after full emergence of seedlings. The 
other agricultural recommended practices for growing sesame were followed.

\subsection{Data recorded}

Weeds were hand pulled from one square meter randomly from each plot at 75 days after sowing and classified to broadleaved and grassy weeds and were air dried for seven days and then oven dried at $70{ }^{\circ} \mathrm{C}$ until reaching a constant weight. Dry weight of broadleaved weeds, grassy weeds and total dry weight of weeds were recorded.

At full maturity stage, sample of ten sesame plants were taken at random from each experimental unit at physiological maturity to measure plant height, the number of branches/plant, fruiting zone length, the number of capsules /plant, capsule length, seed yield/plant, 1000-seed weight.

Seed and oil yield /feddan were estimated as following equations:

$$
\text { Seed yield }(\mathrm{kg} / \text { feddan })=\frac{\text { Seed weigh }(\mathrm{kg}) \quad \mathrm{X} 4200}{\text { Harvested } \operatorname{area}\left(\mathrm{m}^{2}\right)}
$$

Oil yield $(\mathrm{kg} /$ feddan $=$

Seed oil content $(\%) \mathrm{X}$ seed yield ( $\mathrm{kg} /$ feddan)

Oil content (\%): The crude oil of sesame seed was determined by Suxhlet extraction method according to (A.O.A.C) 1990.

\subsection{Statistical Analysis:}

Statistical analysis was carried out according to Gomez and Gomez (1984) using MSTAT-C computer software (Freed et al.,1989).

\section{RESULTS AND DISCUSSION}

\section{1. Effect of water regime on annual weeds}

The presented weeds in this study were Xanthium strumarium L, (Cocklebur) and Ipomoea eriocarpa (Morning glory) and Portulaca oleracea, L. (Common purslane) as broadleaved weeds and Echinochloa colonum) (L.) Link. (Barnyard grass) as grassy weed in first season and by Xanthium strumarium L. and Corchorus olitorius, L. (Nalta jute); as broadleaved weeds and Echinochloa colonum, (L.) Link. as grassy weed in the second season. It was noticed that Xanthium strumarium L. as broadleaved and Echinochloa colonum L. as grassy weed were the predominant weeds in both seasons.

Data in Table (2). revealed that water regimes had significant effect on the dry weight of annual weeds in both seasons. Irrigation at $60 \%$ FC reduced the dry weight of broad leaved, grassy and total annual weeds by 40.0, 29.7 and $36.2 \%$, respectively, in the first season and by $34.0,43.2$ and $37.5 \%$, respectively, in the second season. While, irrigation at $80 \%$ of FC gave 19.1, 20.6 and $19.6 \%$ reduction, respectively, in the first season and by 16.0, 27.2 and $20.2 \%$, respectively, in the second season, as compared to $100 \%$ of FC.

\section{2. Effect of water regime on growth, yield and yield components of sesame:-}

Results in Table 3 showed that water regime significantly affected agronomical traits of sesame except fruiting zone length in both seasons. Irrigation at $100 \%$ of FC gave the tallest plants $(197.4$ and $201.4 \mathrm{~cm})$ than irrigation at $60 \%$ of FC (175.6 and $180.0 \mathrm{~cm})$, respectively in both seasons. Also, irrigation at $100 \%$ of FC gave the highest number of branches / plant (2.81 and 2.91, respectively) in both seasons than irrigation at $60 \%$ FC (2.23 and 2.33, respectively).

These results are in harmony with those obtained by Hong et al. (1985).

Data presented in Table (3) revealed that water regime had significant effect on capsule number/plant and seed oil \% in the first season, capsule length, 1000- grain weight and yield /fed. in both seasons. Capsule number/plant was increased by irrigation at $100 \%$ and $80 \%$ of FC by 15.2 and $3.8 \%$, respectively, in the first season. So, capsule length was increased by irrigation at $100 \%$ and $80 \%$ of FC by 13.4 and $9.3 \%$, respectively, in the first season and by 15.2 and $12.9 \%$, respectively, in the second season. The highest 1000- grain weight was obtained from irrigation at $100 \%$ and $80 \%$ of FC by 11.8 and $6.2 \%$, respectively, in the first season and by 14.0 and $9.0 \%$, respectively, in the second season. Irrigation at $100 \%$ and $80 \%$ of FC increased seed yield/ fed. by 26.9 and 19.8 $\%$, respectively, in the first season and by 21.8 and $10.3 \%$, respectively, in the second season compared to irrigation at $60 \%$ of FC. The same trend was observed with seed oil \% in the first season. These results are in harmony with those obtained by Ucan et al. (2007), Ahmed et al. (2010) and Damdar et al.(2014).

\section{3. Effect of water regime on water consumptive use (CU) and water use efficiency (WUE)}

Results presented in Table (4), show the effect of water regime on water consumptive use and water use efficiency by sesame crop. Water consumptive use values were 2252.6, 2016.1, 1656.9, 2261.7, 2020.4 and 1654.2 $\mathrm{m}^{3} /$ fed for irrigation at 100,80 and $60 \%$ of $\mathrm{FC}$, respectively, in both seasons. Results indicate that irrigation at 80 and $60 \%$ of $\mathrm{FC}$ reduced 
Table (2): Effect of water regimes on dry weight $\left(\mathrm{g} / \mathrm{m}^{2}\right)$ of annual weeds $\left(\mathrm{g} / \mathrm{m}^{2}\right)$ in 2012 and 2013 summer seasons.

\begin{tabular}{|c|c|c|c|c|c|c|}
\hline \multirow{3}{*}{$\begin{array}{l}\text { Water regime } \\
\% \text { of Field } \\
\text { Capacity }\end{array}$} & \multicolumn{6}{|c|}{ Annual weeds dry weight $\left(\mathrm{g} / \mathrm{m}^{2}\right)$} \\
\hline & $\begin{array}{l}\text { Broad } \\
\text { leaved } \\
\text { weeds }\end{array}$ & $\begin{array}{l}\text { Grassy } \\
\text { weeds }\end{array}$ & $\begin{array}{c}\text { Total } \\
\text { weeds }\end{array}$ & $\begin{array}{l}\text { Broad } \\
\text { leaved } \\
\text { weeds }\end{array}$ & $\begin{array}{c}\text { Grassy } \\
\text { weeds }\end{array}$ & Total weeds \\
\hline & \multicolumn{3}{|c|}{2012 season } & \multicolumn{3}{|c|}{2013 season } \\
\hline 100 & 196.8 & 114.3 & 311.1 & 198.4 & 120.1 & 318.5 \\
\hline 80 & 159.3 & 90.8 & 250.1 & 166.7 & 87.4 & 254.1 \\
\hline 60 & 118.1 & 80.4 & 198.5 & 130.9 & 68.2 & 199.2 \\
\hline L.S.D 0.05 & 21.3 & 9.0 & 26.7 & 43.7 & 21.3 & 50.8 \\
\hline
\end{tabular}

Table (3): Effect of water regimes on growth, yield and yield components in 2012 and 2013 summer seasons.

\begin{tabular}{|c|c|c|c|c|c|c|c|c|}
\hline \multirow{3}{*}{$\begin{array}{l}\text { Growth, yield } \\
\text { and yield } \\
\text { components }\end{array}$} & \multicolumn{4}{|c|}{ Water regime \% of Field Capacity } & \multicolumn{4}{|c|}{ Water regime \% of Field Capacity } \\
\hline & 100 & 80 & 60 & L.S.D 0.05 & 100 & 80 & 60 & L.S.D 0.05 \\
\hline & \multicolumn{4}{|c|}{2012 season } & \multicolumn{4}{|c|}{2013 season } \\
\hline $\begin{array}{c}\text { Plant height } \\
(\mathrm{cm})\end{array}$ & 197.4 & 185.2 & 175.6 & 12.7 & 201.4 & 189.3 & 180.0 & 10.7 \\
\hline $\begin{array}{c}\text { Branches /plant } \\
\text { (No) }\end{array}$ & 2.81 & 2.50 & 2.23 & 0.05 & 2.91 & 2.63 & 2.33 & 0.13 \\
\hline $\begin{array}{l}\text { Fruiting zone } \\
\text { length }(\mathbf{c m})\end{array}$ & 111.3 & 96.9 & 89.7 & ns & 108.3 & 94.1 & 91.8 & ns \\
\hline $\begin{array}{c}\text { Capsules /plant } \\
\text { (no) }\end{array}$ & 141.7 & 124.9 & 120.1 & 11.36 & 165.6 & 147.2 & 134.9 & ns \\
\hline $\begin{array}{c}\text { Capsule length } \\
(\mathrm{cm})\end{array}$ & 3.82 & 3.65 & 3.31 & 0.18 & 4.14 & 4.03 & 3.51 & 0.16 \\
\hline $\begin{array}{l}\text { Seed yield/plant } \\
(\mathrm{g})\end{array}$ & 25.8 & 23.8 & 21.0 & ns & 27.50 & 24.06 & 23.00 & ns \\
\hline $\begin{array}{l}\text { 1000- seed } \\
\text { weight }(\mathrm{g})\end{array}$ & 4.99 & 4.69 & 4.40 & 0.16 & 5.08 & 4.80 & 4.37 & 0.24 \\
\hline $\begin{array}{l}\text { Seed yield /fed. } \\
\text { (kg) }\end{array}$ & 778.0 & 709.0 & 568.7 & 28.8 & 749.7 & 653.3 & 586.0 & 23.4 \\
\hline Oil \% & 50.04 & 49.95 & 49.68 & 0.20 & 51.25 & 51.29 & 50.42 & ns \\
\hline
\end{tabular}

Table (4): Effect of water regimes on seed yield, consumptive use (CU) and water use efficiency (WUE) in 2012 and 2013 seasons.

\begin{tabular}{|c|c|c|c|c|c|c|}
\hline \multirow{2}{*}{$\begin{array}{c}\text { Water regime } \\
\text { of FC* \% }\end{array}$} & $\begin{array}{c}\text { CU } \\
(\mathbf{m m})\end{array}$ & $\begin{array}{c}\text { Seed yield } \\
\text { /fed. }(\mathbf{k g})\end{array}$ & $\begin{array}{c}\text { WUE } \\
\left(\mathbf{K g} / \mathbf{m}^{\mathbf{3}}\right)\end{array}$ & $\begin{array}{c}\text { CU } \\
(\mathbf{m m})\end{array}$ & $\begin{array}{c}\text { Seed yield } \\
\text { /fed. }(\mathbf{k g})\end{array}$ & $\begin{array}{c}\text { WUE } \\
\left(\mathbf{K g} / \mathbf{m}^{\mathbf{3}}\right)\end{array}$ \\
\cline { 2 - 7 } $\mathbf{1 0 0}$ & \multicolumn{3}{|c|}{$\mathbf{2 0 1 3}$ season } \\
\hline $\mathbf{2} 252.6$ & 778.0 & 0.345 & $\begin{array}{c}2261.7 \\
(53.9 \mathrm{~cm})\end{array}$ & $\mathbf{2 0 1 3}$ season \\
\hline $\mathbf{8 0}$ & $\begin{array}{c}2016.1 \\
(48.0 \mathrm{~cm})\end{array}$ & 709.0 & 0.352 & $\begin{array}{c}2020.4 \\
(48.1 \mathrm{~cm})\end{array}$ & 653.3 & 0.329 \\
\hline $\mathbf{6 0}$ & $\begin{array}{c}1656.9 \\
(39.5 \mathrm{~cm})\end{array}$ & 568.7 & 0.343 & $\begin{array}{c}1654.2 \\
(39.4 \mathrm{~cm})\end{array}$ & 586.0 & 0.335 \\
\hline L.S.D $\mathbf{0 . 0 5}$ & $\mathbf{6 6 . 0 2}$ & $\mathbf{2 8 . 8}$ & $\mathbf{0 . 0 3}$ & $\mathbf{8 7 . 4}$ & $\mathbf{2 3 . 4}$ & $\mathbf{0 . 0 2}$ \\
\hline
\end{tabular}

* Field Capacity (FC) 
water consumptive use by $26.4,10.5,26.9$ and $10.7 \%$, respectively, in both seasons as compared to irrigation at $100 \%$ of FC. The obtained results are in agreement with those of Metwally et al., (1984) and Attia et al. (1999). Who reported that water consumptive use values of sesame crop varied from 41 to $53 \mathrm{~cm} / \mathrm{fed}$ at Giza and from 36 to $49 \mathrm{~cm} / \mathrm{fed}$ at the calcareous soils of Nubaria area.

The calculated water use efficiency values as affected by the tested variables are presented in Table (4). Results reveal that WUE values were $0.345,0.352$ and $0.343 \mathrm{~kg}$ $\mathrm{seed} / \mathrm{m}^{3}$ water consumed for the irrigation at 100,80 and $60 \%$ of FC, respectively in the first season and $0.329,0.335$ and $0.334 \mathrm{~kg}$ seed $/ \mathrm{m}^{3}$ water consumed, respectively in the second season. The obtained results are in agreement with those of Damdar et al. (2014).

The highest WUE value $(0.352$ and $0.335 \mathrm{~kg}$ $\mathrm{seed} / \mathrm{m}^{3}$ water consumed) in the first and second seasons resulted from irrigation at $80 \%$ of FC.

\subsection{Effect of cultivars on annual weeds:}

As shown in Table (5) the dry weight of broad leaved and the total annual weeds were reduced significantly with sowing Sohag 2000 cultivar by 15.2 and $9.9 \%$, respectively, in the first season. In the second season, the reduction in the dry weight of broad leaved, grassy weeds and total annual weeds with Sohag 2000 cultivar were $16.2,16.9$ and $38.4 \%$, respectively, as compared with Shandaweel 3 cultivar. These results may be due to the fact that plants of Sohag 2000 cultivar were more taller and had higher number of branches and can overcome weed competitions in camparison with Shandaweel 3 cultivar. These finding are are in harmony with those reported by Rehab and Fakkar (2007).

\section{3..5. Effect of cultivars on growth, yield and yield components of sesame}

Results in Table (6) indicated that the varieties significantly differed in growth traits, except fruiting zone length in the second season and plant height in both seasons.

Sohag-2000 cultivar gave the highest number of branches / plant (3.19 and 3.30), respectively, in both seasons than Shandaweel 3 (1.84 and 1.95). Also, the fruiting zone length of Sohag 2000 cultivar was the longest $(103.4 \mathrm{~cm})$, compared to Shandaweel $3(95.2 \mathrm{~cm})$ in the first season only. These results are in harmony with those of Basha (1998), Basha and Awaad (2000),
Abdel-Wahab et al. (2005) as well as Rehab and Fakkar (2007).

Results in Table (6) cleared that sesame cultivars were significantly different in capsule number /plant, capsule length and seed yield/plant in 2012 and 2013 seasons.

Sohag-2000 gave the highest values for the above characteristics in both seasons compared to Shandaweel 3. Seed yield/plant of Sohag 2000 exceeded that of Shandaweel 3 by 18.5 and $21.2 \%$, respectively, in the first and second seasons. Similar results were obtained by Basha (1998), Basha and Awaad (2000), Abdel-Wahab et al.(2005), Abo-El-Wafa and Abdel-Laltief (2006), Rehab and Fakkar (2007) Hassanzadeh et al., (2009) and Kassab et al. (2012).

3.6. Effect of cultivars on water consumptive use (CU) and water use efficiency (WUE)

For water consumptive use $(\mathrm{CU})$ results in Table (7) showed also that, there were slight difference in total consumptive use between the two cultivars. Sohag 2000 cultivar increased consumptive use by 2.7 and $2.8 \%$ in both seasons, compared to Shandaweel-3 cultivar.

For water use efficiency (WUE) results in Table (7) indicate that Sohag 2000 cultivar gave the highest values of water use efficiency $\left(\mathrm{Kg} / \mathrm{m}^{3}\right)$ by $\left(0.361\right.$ and $0.344 \mathrm{~kg} \mathrm{seed} / \mathrm{m}^{3}$ water consumed, respectively) in both seasons, compared to Shandaweel 3 cultivar. Similar results were obtained by Kassab et al.(2012)

\subsection{Effect of weed control treatments on annual weeds:}

All tested weed control treatments significantly reduced the dry weight of annual broad-leaved, grassy weeds and their total in comparison with unweeded treatment in both seasons (Table 8). The superior treatments on reduction $\%$ of broad-leaved weeds were hand hoeing twice, bentazon followed by H.H. once, prometryn followed by H.H. once and bentazon alone by $97.7,97.1,96.4$ and $95.7 \%$, in the first season, and 99.3, 98.4, 96.3 and $93.6 \%$ in the second season, respectively, compared to unweeded treatment. While, The superior treatments in reduction \% of grassy weeds were hand hoeing twice, prometryn followed by H.H. once, bentazon followed by H.H. once and prometryn alone, by $90.1,86.7,82.1$ and 56.7 $\%$,respectively in the first season. In the second season, hand hoeing twice, bentazon followed by H.H. once prometryn followed by H.H. once and prometryn alone, and 99.5, 90.3, 89.3 and $77.6 \%$, respectively, compared to un- weeded treatment 
Table (5): Effect of cultivars on the dry weight of annual weeds $\left(\mathrm{g} / \mathrm{m}^{2}\right)$ in 2012 and 2013 summer seasons.

\begin{tabular}{|c|c|c|c|c|c|c|}
\hline \multirow{3}{*}{$\begin{array}{l}\text { Sesame } \\
\text { cultivars }\end{array}$} & \multicolumn{6}{|c|}{ Annual weeds dry weight $\left(\mathrm{g} / \mathrm{m}^{2}\right)$} \\
\hline & $\begin{array}{l}\text { Broad } \\
\text { leaved } \\
\text { weeds }\end{array}$ & $\begin{array}{c}\text { Grassy } \\
\text { weeds }\end{array}$ & $\begin{array}{c}\text { Total } \\
\text { weeds }\end{array}$ & $\begin{array}{l}\text { Broad } \\
\text { leaved } \\
\text { weeds }\end{array}$ & $\begin{array}{c}\text { Grassy } \\
\text { weeds }\end{array}$ & Total weeds \\
\hline & \multicolumn{3}{|c|}{2012 season } & \multicolumn{3}{|c|}{2013 season } \\
\hline Shandaweel 3 & 171.1 & 95.4 & 266.5 & 179.9 & 100.4 & 380.3 \\
\hline Sohag 2000 & 145.1 & 94.9 & 240.0 & 150.8 & 83.4 & 234.2 \\
\hline F-test & $* *$ & ns & $* *$ & $* *$ & $* *$ & $* *$ \\
\hline
\end{tabular}

Table (6): Effect of cultivars on growth, yield and yield components in 2012 and 2013 summer seasons.

\begin{tabular}{|c|c|c|c|c|c|c|}
\hline \multirow{2}{*}{$\begin{array}{c}\text { Growth , yield and yield } \\
\text { components }\end{array}$} & \multicolumn{3}{|c|}{ Sesame cultivars } & \multicolumn{3}{c|}{ Sesame cultivars } \\
\cline { 2 - 8 } & $\begin{array}{c}\text { Shandaweel } \\
\mathbf{3}\end{array}$ & $\begin{array}{c}\text { Sohag } \\
\mathbf{2 0 0 0}\end{array}$ & \multirow{2}{*}{ F-test } & $\begin{array}{c}\text { Shandaweel } \\
\mathbf{3}\end{array}$ & $\begin{array}{c}\text { Sohag } \\
\mathbf{2 0 0 0}\end{array}$ & \multirow{2}{*}{ F-test } \\
\cline { 2 - 8 } & \multicolumn{3}{|c|}{ season } & \multicolumn{3}{c|}{$\mathbf{2 0 1 3}$ season } \\
\hline Plant height (cm) & 183.9 & 188.2 & ns & 192.7 & 187.7 & ns \\
\hline Branches /plant (No) & 1.84 & 3.19 & $*$ & 1.95 & 3.30 & $*$ \\
\hline Fruiting zone length (cm) & 95.2 & 103.4 & $* *$ & 94.4 & 101.7 & ns \\
\hline Capsules /plant (no) & 132.9 & 124.9 & & 153.0 & 145.4 & ns \\
\hline Capsule length (cm) & 3.61 & 3.58 & ns & 4.07 & 3.72 & $*$ \\
\hline Seed yield/plant (g) & 25.9 & 21.1 & $*$ & 27.8 & 21.9 & $*$ \\
\hline 1000- seed weight (g) & 4.63 & 4.75 & $*$ & 4.70 & 4.80 & $*$ \\
\hline Seed yield /fed. (kg) & 648.7 & 721.8 & $* *$ & 635.8 & 690.2 & $* *$ \\
\hline Oil \% & 49.94 & 49.83 & $*$ & 51.32 & 50.64 & $*$ \\
\hline
\end{tabular}

Table (7): Effect of cultivars on yield and water relations in the two summer seasons.

\begin{tabular}{|c|c|c|c|c|c|c|}
\hline \multirow[b]{2}{*}{$\begin{array}{l}\text { Sesame } \\
\text { cultivars }\end{array}$} & \multicolumn{6}{|c|}{ Yield and water relations } \\
\hline & $\begin{array}{c}\text { CU } \\
\left(\mathbf{m}^{3} / \text { fed. }\right)\end{array}$ & $\begin{array}{l}\text { Seed yield } \\
\text { /fed. (kg) }\end{array}$ & $\begin{array}{c}\text { WUE } \\
\left(\mathrm{Kg} / \mathrm{m}^{3}\right)\end{array}$ & $\begin{array}{c}\text { CU } \\
\left(\mathrm{m}^{3} / \text { fed. }\right)\end{array}$ & $\begin{array}{l}\text { Seed yield } \\
\text { /fed. }(\mathrm{kg})\end{array}$ & $\begin{array}{c}\text { WUE } \\
\left(\mathrm{Kg} / \mathrm{m}^{3}\right)\end{array}$ \\
\hline & \multicolumn{3}{|c|}{2012 season } & \multicolumn{3}{|c|}{2013 season } \\
\hline Shandaweel 3 & $\begin{array}{c}1948.0 \\
(46.4 \mathrm{~cm})\end{array}$ & 5.41 & 0.333 & $\begin{array}{c}1951.1 \\
(46.5 \mathrm{~cm})\end{array}$ & 5.30 & 0.326 \\
\hline Sohag 2000 & $\begin{array}{c}2002.4 \\
(47.7 \mathrm{~cm})\end{array}$ & 6.02 & 0.361 & $\begin{array}{c}2006.5 \\
(47.8 \mathrm{~cm})\end{array}$ & 5.75 & 0.344 \\
\hline F-test & $* *$ & $*$ & $*$ & $* *$ & $*$ & $*$ \\
\hline
\end{tabular}

Table (8): Effect of weed control treatments on dry weight of annual weeds $\left(\mathrm{g} / \mathrm{m}^{2}\right)$ in 2012 and 2013 summer seasons.

\begin{tabular}{|c|c|c|c|c|c|c|}
\hline \multirow[b]{2}{*}{ Weed control treatments } & \multicolumn{6}{|c|}{ Annual weeds dry weight $\left(\mathrm{g} / \mathrm{m}^{2}\right)$} \\
\hline & $\begin{array}{c}\text { Broad } \\
\text { leaved } \\
\text { weeds } \\
(\mathrm{gm}) \\
\end{array}$ & $\begin{array}{c}\text { Grassy } \\
\text { weeds } \\
\text { (gm) }\end{array}$ & $\begin{array}{c}\text { Total } \\
\text { weeds } \\
(\mathrm{gm})\end{array}$ & $\begin{array}{c}\text { Broad } \\
\text { leaved } \\
\text { weeds } \\
(\mathrm{gm}) \\
\end{array}$ & $\begin{array}{c}\text { Grassy } \\
\text { weeds } \\
\text { (gm) }\end{array}$ & $\begin{array}{l}\text { Total weeds } \\
\text { (gm) }\end{array}$ \\
\hline & \multicolumn{6}{|c|}{2012 season } \\
\hline Prometryn & 365.4 & 92.3 & 457.8 & 410.9 & 53.0 & 463.9 \\
\hline Bentazon & 22.4 & 197.9 & 220.3 & 33.3 & 213.2 & 246.5 \\
\hline Prometryn + H.H once & 18.6 & 38.1 & 56.6 & 18.9 & 22.8 & 41.7 \\
\hline Bentazon + H.H once & 15.0 & 28.4 & 43.5 & 8.4 & 25.3 & 33.7 \\
\hline Hand hoeing twice & 11.7 & 21.1 & 12.8 & 3.7 & 1.1 & 4.8 \\
\hline Untreated (check) & 515.3 & 213.2 & 728.5 & 516.7 & 236.1 & 752.7 \\
\hline L.S.D ${ }_{0.05}$ & 29.2 & 12.3 & 31.4 & 30.7 & 23.0 & 40.1 \\
\hline
\end{tabular}


Actually, hand hoeing twice, prometryn followed by H.H. once, bentazon followed by H.H. once gave the highest reduction $\%$ on total weeds by $98.2,94.0$ and $92.2 \%$, respectively, in the first season, and 99.4, 95.4 and $94.3 \%$, respectively, in the second season, compared to un-weeded treatment. Bentazon gave reduction $\%$ on weeds because they killed broadleaf weeds only. These results are in agreement with those obtained by Joshi (1985).

3.8. Effect of weed control treatments on growth, yield and yield components of sesame

Results in Table (9) show that weed control treatments significantly affected the tested agronomical traits except fruiting zone length in both seasons.

The tallest sesame plants were observed with using hand hoeing twice, prometryn + hand hoeing once and bentazon followed by hand hoeing once compared to other weed control treatments in the first season. In the second season, the same trend was obtained from hand hoeing twice, prometryn application followed by hand hoeing once and bentazon, followed by hand hoeing once compared to other weed control treatments.

Controlling weeds by using hand hoeing twice, prometryn application followed by hand hoeing once and bentazon application followed by hand hoeing once, gave the highest number of branches /plant ( 3.24, 2.79 and 2.71, respectively, in the first season and 3.36, 2.91 and 2.82 , respectively, in the second season) compared to other weed control treatments (Table 9).

Results in Table (9) show that weed control treatments significantly affected yield and yield components in both seasons. Using hand hoeing twice, prometryn or bentazon followed by hand hoeing once, resulted in the highest capsule number /plant and capsule length in both seasons. The same trend was obtained with seed yield/plant which increased by $43.4,34.1$ and $24.4 \%$, respectively, in the first season and by $47.0,37.5$ and $31.4 \%$, respectively, in the second season, compared to the un-weeded. Using hand hoeing twice, prometryn or bentazon followed by hand hoeing once gave the highest 1000 -grain weight ( $27.3,24.2$ and $21.5 \%$, respectively, in the first season and by $24.6,21.2$ and $18.0 \%$, respectively, in the second season ) compared to the un-weeded. Using hand hoeing twice, bentazon herbicide followed by hand hoeing once and prometryn herbicide followed by hand hoeing once increased seed yield by $35.8,33.8$ and $31.3 \%$, respectively, in the first season and by 35.6, 30.7 and $27.5 \%$, respectively, in the second season compared to the un-weeded treatment. The highest seed content of oil was obtained with hand hoeing twice, prometryn or bentazon followed by hand hoeing once $(54.53,51.14$ and 50.80, respectively, in the first season and by 53.64 , 52.41 and 50.44, respectively, in the second season) compared to the un-weeded treatment. These results are in harmony with those reported by Rehab and Fakkar (2007).

3.8.1. Effect of weed control treatments on water consumptive use (CU) and water use efficiency (WUE)

For water consumptive use (CU) results presented in Table (10), showed that the effect of weed control treatments on water consumptive use by sesame crop. Using hand hoeing twice, prometryn + hand hoeing once and bentazon + hand hoeing once for controlling weeds increased water consumptive use by 13.9, 11.9, $9.6,13.9,11.9$ and $9.5 \%$, respectively, compared to the untreated .

For water use efficiency (WUE) results in Table (10) reveal that using hand hoeing twice, bentazon followed by hand hoeing once and prometryn followed by hand hoeing once gave the highest values of water use efficiency compared to the untreated.

The highest WUE value resulted from hand hoeing twice or bentazon + hand hoeing once or prometryn followed by hand hoeing with Sohag 2000 variety under $80 \%$ of FC irrigation which may be recommended for cultivating sesame under conditions of Sohag Governorate, Egypt.

\subsection{Effect of interactions.}

\subsection{Effect of the interactions between water regimes and sesame cultivars}

Data in Table (11) reveal that all interactions between water regimes and sesame cultivars had statically significant effect on branch number /plant and seed yield/ plant in both seasons and capsule number /plant, capsule length, water consumptive use and water use efficiency in the first season meaning that the two factors act independently. Generally, the highest values of all characteristics above were obtained when sesame plants of Sohag-2000 cultivar were irrigated with $100 \%$ of FC water regime, compared to Shandawee 1-3 cultivar with 


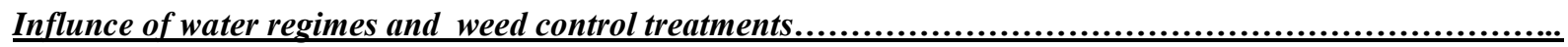

Table (9): Effect of weed control treatments on growth, yield and yield component of sesame in 2012 and 2013 summer seasons.

\begin{tabular}{|c|c|c|c|c|c|c|c|}
\hline \multirow[b]{2}{*}{$\begin{array}{l}\text { Weed control } \\
\text { treatments }\end{array}$} & \multicolumn{7}{|c|}{ Growth, yield and yield component } \\
\hline & $\begin{array}{c}\text { Prometry } \\
\text { n }\end{array}$ & Bentazon & $\begin{array}{c}\text { Prometry } \\
\mathbf{n}+\text { H.H } \\
\text { once }\end{array}$ & $\begin{array}{c}\text { Bentazon } \\
+ \text { H.H } \\
\text { once } \\
\end{array}$ & $\begin{array}{c}\text { Hand } \\
\text { hoeing } \\
\text { twice }\end{array}$ & $\begin{array}{c}\text { Untreate } \\
\text { d } \\
\text { (check) }\end{array}$ & $\begin{array}{c}\text { L.S.D } \\
0.05\end{array}$ \\
\hline \multicolumn{8}{|c|}{2012 season } \\
\hline Plant height (cm) & 175.7 & 180.2 & 190.2 & 190.9 & 209.7 & 169.6 & 10.4 \\
\hline Branches /plant (No) & 2.14 & 2.33 & 2.71 & 2.79 & 3.24 & 1.87 & $\mathbf{0 . 1 2}$ \\
\hline $\begin{array}{l}\text { Fruiting zone length } \\
(\mathrm{cm})\end{array}$ & 94.5 & 99.0 & 101.1 & 98.9 & 98.5 & 103.9 & ns \\
\hline Capsules /plant (no) & 123.0 & 125.3 & 133.7 & 134.3 & 141.2 & 116.2 & 14.34 \\
\hline Capsule length $(\mathrm{cm})$ & 3.35 & 3.51 & 3.76 & 3.88 & 3.49 & 3.13 & 0.18 \\
\hline Seed yield/plant $(\mathrm{g})$ & 20.1 & 20.2 & 23.8 & 27.3 & 31.8 & 18.0 & 2.77 \\
\hline 1000- seed weight $(\mathrm{g})$ & 4.14 & 4.26 & 5.06 & 5.24 & 5.46 & 3.97 & 0.08 \\
\hline Seed yield /fed. (kg) & 579.3 & 608.7 & 770.0 & 800.0 & 824.0 & 529.3 & 27.5 \\
\hline Oil \% & 48.38 & 47.93 & 51.14 & 50.80 & 54.53 & 46.53 & 0.11 \\
\hline \multicolumn{8}{|c|}{2013 season } \\
\hline Plant height $(\mathrm{cm})$ & 180.6 & 184.8 & 192.8 & 195.9 & 213.6 & 173.7 & 9.3 \\
\hline Branches /plant (No) & 2.25 & 2.44 & 2.82 & 2.91 & 3.36 & 1.97 & 0.12 \\
\hline $\begin{array}{c}\text { Fruiting zone length } \\
(\mathrm{cm})\end{array}$ & 94.2 & 99.2 & 96.5 & 100.2 & 98.0 & 100.4 & n.s \\
\hline Capsules /plant (no) & 138.3 & 150.0 & 153.4 & 157.0 & 160.8 & 135.7 & 14.52 \\
\hline Capsule length $(\mathrm{cm})$ & 3.67 & 3.76 & 4.06 & 3.99 & 4.19 & 3.69 & 0.22 \\
\hline Seed yield/plant (g) & 21.44 & 23.28 & 25.61 & 28.11 & 33.11 & 17.56 & 2.85 \\
\hline 1000- seed weight (g) & 4.24 & 4.34 & 5.05 & 5.24 & 5.48 & 4.13 & 0.08 \\
\hline Seed yield /fed. (kg) & 564.7 & 603.3 & 721.3 & 754.0 & 811.3 & 522.7 & 25.1 \\
\hline Oil \% & 50.44 & 49.06 & 50.01 & 52.41 & 53.64 & 50.35 & 0.75 \\
\hline
\end{tabular}

Table (10): Effect of weed control treatments on water consumptive use (CU), water use efficiency (WUE) and seed yield/ fed.

\begin{tabular}{|c|c|c|c|c|c|c|}
\hline \multirow{3}{*}{$\begin{array}{l}\text { Weed control } \\
\text { Treatments }\end{array}$} & \multicolumn{6}{|c|}{ Yield and moisture studies } \\
\hline & $\begin{array}{c}\text { CU } \\
\left(\mathbf{m}^{3} / \text { fed. }\right)\end{array}$ & $\begin{array}{l}\text { Seed yield } \\
\text { /fed. (kg) }\end{array}$ & $\begin{array}{c}\text { WUE } \\
\left(\mathrm{Kg} / \mathbf{m}^{3}\right)\end{array}$ & $\begin{array}{c}\text { CU } \\
\left(\mathbf{m}^{3} / \text { fed. }\right)\end{array}$ & $\begin{array}{l}\text { Seed yield } \\
\text { /fed. (kg) }\end{array}$ & $\begin{array}{c}\text { WUE } \\
\left(\mathrm{Kg} / \mathrm{m}^{3}\right)\end{array}$ \\
\hline & \multicolumn{3}{|c|}{2012 season } & \multicolumn{3}{|c|}{2013 season } \\
\hline Prometryn & $\begin{array}{c}1909.4 \\
(45.5 \mathrm{~cm})\end{array}$ & 579.3 & 0.304 & $\begin{array}{c}1911.7 \\
(45.5 \mathrm{~cm})\end{array}$ & 564.7 & 0.296 \\
\hline Bentazon & $\begin{array}{c}1948.1 \\
(46.4 \mathrm{~cm})\end{array}$ & 608.7 & 0.312 & $\begin{array}{c}1951.2 \\
(46.5 \mathrm{~cm})\end{array}$ & 603.3 & 0.309 \\
\hline $\begin{array}{l}\text { Prometryn + H.H } \\
\text { once }\end{array}$ & $\begin{array}{c}2007.7 \\
(47.8 \mathrm{~cm})\end{array}$ & 770.0 & 0.384 & $\begin{array}{c}2012.1 \\
(47.9 \mathrm{~cm})\end{array}$ & 721.3 & 0.358 \\
\hline $\begin{array}{l}\text { Bentazon + H.H } \\
\text { once }\end{array}$ & $\begin{array}{c}2061.6 \\
(49.1 \mathrm{~cm})\end{array}$ & 800.0 & 0.388 & $\begin{array}{c}2066.8 \\
(49.2 \mathrm{~cm})\end{array}$ & 754.0 & 0.365 \\
\hline hand hoeing twice & $\begin{array}{c}2108.8 \\
(50.2 \mathrm{~cm})\end{array}$ & 824.0 & 0.391 & $\begin{array}{c}2115.1 \\
(50.4 \mathrm{~cm})\end{array}$ & 811.3 & 0.384 \\
\hline Untreated (check) & $\begin{array}{c}1815.5 \\
(43.2 \mathrm{~cm})\end{array}$ & 529.3 & 0.291 & $\begin{array}{c}1816.0 \\
(43.2 \mathrm{~cm})\end{array}$ & 522.7 & 0.288 \\
\hline L.S.D 0.05 & 7.09 & 27.5 & 0.02 & 9.35 & 25.1 & $\mathbf{0 . 0 3}$ \\
\hline
\end{tabular}


Table (11): Effect of water regimes and cultivars on sesame yield and yield components and moisture studies in 2012and 2013 summer seasons.

\begin{tabular}{|c|c|c|c|c|c|c|c|}
\hline \multirow{4}{*}{ Sesame characters } & \multicolumn{6}{|c|}{ Water regimes } & \multirow{3}{*}{ L.S.D. 0.05} \\
\hline & \multicolumn{2}{|c|}{$100 \% \mathrm{FC}$} & \multicolumn{2}{|c|}{$80 \%$ FC } & \multicolumn{2}{|c|}{$60 \% \mathrm{FC}$} & \\
\hline & Shandaweel 3 & $\begin{array}{c}\text { Sohag } \\
2000\end{array}$ & $\begin{array}{c}\text { Shandawee } \\
13\end{array}$ & $\begin{array}{c}\text { Sohag } \\
2000\end{array}$ & $\begin{array}{c}\text { Shandaweel } \\
3\end{array}$ & $\begin{array}{c}\text { Sohag } \\
2000\end{array}$ & \\
\hline & \multicolumn{7}{|c|}{2012 season } \\
\hline Branches / plant (No) & 2.22 & 3.59 & 1.88 & 3.38 & 1.73 & 2.93 & 0.12 \\
\hline Capsule /plant (No) & 131.5 & 151.9 & 129.1 & 120.8 & 114.2 & 126.1 & 13.08 \\
\hline Capsule length $(\mathrm{cm})$ & 3.73 & 3.57 & 3.73 & 3.76 & 3.17 & 4.05 & 0.26 \\
\hline Seed yield/ plant (g) & 22.2 & 29.5 & 21.9 & 25.6 & 19.3 & 22.7 & 0.61 \\
\hline CU (m³/fed.) & 2275.5 & 2229.7 & 2047.8 & 1984.4 & 1683.8 & 1630.0 & 7.36 \\
\hline \multirow[t]{2}{*}{ WUE $\left(\mathrm{Kg} / \mathbf{m}^{3}\right)$} & 0.361 & 0.329 & 0.362 & 0.340 & 0.357 & 0.329 & 0.02 \\
\hline & \multicolumn{7}{|c|}{2013 season } \\
\hline Branches / plant (No) & 2.13 & 3.49 & 1.75 & 3.25 & 1.63 & 2.83 & 0.11 \\
\hline Seed yield/ plant (g) & 24.4 & 30.6 & 23.0 & 25.1 & 18.4 & 27.6 & 3.06 \\
\hline
\end{tabular}

irrigation at $60 \%$ of FC. The highest values of seed yield/plant were produced when sesame plants of Sohag-2000 cultivar were irrigated by $100 \%$ of FC water compared to Shandaweel-3 cultivar with irrigation $60 \%$ of FC.

\subsubsection{Effect of the interactions between water} regimes and weed control treatments

Results in Table (12) indicate that all interactions between water regimes and weed control treatments significantly affect dry weight of annual weeds in both seasons, meaning that the two factors act independently.
Hand hoeing twice, prometryn followed by hand hoeing once and bentazon followed by hand hoeing once gave the lowest dry weight of annual weeds under irrigation at 60 and $80 \%$ of FC water regimes, compared to the same weed control treatments with irrigation at $100 \%$ of FC water regime.

Results in Table (13) show that all interactions between water regime and weed control treatments had no significant effect for all characteristics of yield and yield components under study except for the number of branches

Table (12): Effect of the interaction between water regimes and weed control treatments on annual weeds in 2012and 2013 summer seasons.

\begin{tabular}{|c|c|c|c|c|c|c|c|}
\hline & \multirow{3}{*}{ Treatments } & \multicolumn{6}{|c|}{ Dry weight of annual weeds $\left(\mathrm{g} / \mathrm{m}^{2}\right)$} \\
\hline & & $\begin{array}{l}\text { Broad } \\
\text { leaved } \\
\text { weeds }\end{array}$ & $\begin{array}{c}\text { Grassy } \\
\text { weeds }\end{array}$ & $\begin{array}{c}\text { Total } \\
\text { weeds }\end{array}$ & $\begin{array}{l}\text { Broad } \\
\text { leaved } \\
\text { weeds }\end{array}$ & $\begin{array}{l}\text { Grassy } \\
\text { weeds }\end{array}$ & $\begin{array}{r}\text { Total } \\
\text { weeds }\end{array}$ \\
\hline & & & 12 seas & & & 13 seas & \\
\hline \multirow{6}{*}{$\begin{array}{l}0 \\
0 \\
0 \\
8 \\
\varrho\end{array}$} & Prometryn & 435.0 & 109.3 & 544.3 & 473.5 & 94.0 & 567.5 \\
\hline & Bentazon & 35.2 & 241.2 & 276.4 & 54.4 & 257.7 & 312.1 \\
\hline & Prometryn + H.H & 17.7 & 45.0 & 62.7 & 23.5 & 37.7 & 61.2 \\
\hline & Bentazon + H.H & 18.7 & 32.7 & 51.4 & 13.7 & 40.8 & 54.5 \\
\hline & H.H. twice & 8.8 & 0.0 & 8.8 & 11.2 & 0.0 & 11.2 \\
\hline & Untreated & 665.7 & 257.7 & 923.4 & 614.2 & 290.3 & 904.5 \\
\hline \multirow{6}{*}{$\begin{array}{l}u \\
0 \\
\infty \\
\infty\end{array}$} & Prometryn & 362.0 & 89.5 & 451.5 & 435.0 & 39.0 & 474.0 \\
\hline & Bentazon & 17.2 & 189.7 & 206.9 & 27.5 & 213.3 & 240.8 \\
\hline & Prometryn + H.H & 20.6 & 36.3 & 56.9 & 22.5 & 17.0 & 39.5 \\
\hline & Bentazon + H.H & 17.7 & 25.3 & 43.0 & 11.7 & 25.3 & 37.0 \\
\hline & H.H. twice & 14.9 & 0.0 & 14.9 & 0.0 & 0.0 & 0.0 \\
\hline & Untreated & 523.3 & 204.2 & 727.5 & 503.3 & 229.8 & 733.1 \\
\hline \multirow{6}{*}{$\begin{array}{l}0 \\
0 \\
0 \\
8\end{array}$} & Prometryn & 299.4 & 78.2 & 377.6 & 324.2 & 26.0 & 350.2 \\
\hline & Bentazon & 14.9 & 162.8 & 177.7 & 18.2 & 168.7 & 186.9 \\
\hline & Prometryn + H.H & 17.4 & 32.8 & 50.2 & 10.8 & 13.8 & 24.6 \\
\hline & Bentazon + H.H & 8.7 & 27.3 & 36.0 & 0.0 & 9.6 & 9.6 \\
\hline & H.H. twice & 11.3 & 3.3 & 14.6 & 0.0 & 3.3 & 3.3 \\
\hline & Untreated & 357 & 177.8 & 534.8 & 432.5 & 188.0 & 620.5 \\
\hline \multicolumn{2}{|c|}{ L.S.D. at $5 \%$} & 50.53 & 22.14 & 54.48 & 53.17 & 39.85 & 69.47 \\
\hline
\end{tabular}


Influnce of water regimes and weed control treatments...................................................

Table (13): Effect of the interaction between water regimes and weed control treatments on some studied traits in two summer seasons.

\begin{tabular}{|c|c|c|c|c|c|c|c|}
\hline & \multirow[t]{2}{*}{ Treatments } & $\begin{array}{c}\text { Branches } \\
\text { /plant } \\
\text { (No) }\end{array}$ & $\begin{array}{c}\text { Oil } \\
\%\end{array}$ & $\begin{array}{c}\text { CU } \\
\left(\mathbf{m}^{3} / \text { fed. }\right)\end{array}$ & $\begin{array}{c}\text { Branches } \\
\text { /plant } \\
\text { (No) }\end{array}$ & $\begin{array}{c}\text { Seed } \\
\text { yield/ } \\
\text { plant }(\mathbf{g})\end{array}$ & $\begin{array}{c}\text { CU } \\
\left(\mathbf{m}^{\mathbf{3}} / \mathbf{f e d} .\right)\end{array}$ \\
\hline & & \multicolumn{3}{|c|}{2012 season } & \multicolumn{3}{|c|}{2013 season } \\
\hline \multirow{6}{*}{ 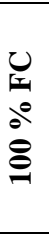 } & Prometryn & 2.50 & 48.3 & 2070.2 & 2.40 & 23.3 & 2075.8 \\
\hline & Bentazon & 2.53 & 48.8 & 2384.7 & 2.43 & 23.5 & 2396.3 \\
\hline & Prometryn + H.H & 3.18 & 51.7 & 2323.7 & 3.08 & 27.7 & 2334.0 \\
\hline & Bentazon + H.H & 3.30 & 50.7 & 2297.3 & 3.20 & 34.3 & 2307.5 \\
\hline & H.H. twice & 3.75 & 54.3 & 2247.2 & 3.65 & 35.3 & 2256.2 \\
\hline & Untreated & 2.17 & 46.4 & 2192.5 & 2.08 & 20.8 & 2200.5 \\
\hline \multirow{6}{*}{$\begin{array}{l}\text { U } \\
8 \\
\infty \\
\infty\end{array}$} & Prometryn & 2.18 & 48.4 & 1880.3 & 2.05 & 18.2 & 1882.0 \\
\hline & Bentazon & 2.48 & 47.8 & 2144.5 & 2.35 & 21.3 & 2151.5 \\
\hline & Prometryn + H.H & 2.83 & 50.2 & 2111.7 & 2.70 & 26.8 & 2118.0 \\
\hline & Bentazon + H.H & 2.88 & 51.1 & 2063.8 & 2.75 & 28.0 & 2069.2 \\
\hline & H.H. twice & 3.43 & 54.6 & 1967.8 & 3.80 & 35.8 & 1971.2 \\
\hline & Untreated & 1.98 & 46.0 & 1928.5 & 1.85 & 14.2 & 1930.8 \\
\hline \multirow{6}{*}{$\begin{array}{l}\text { U } \\
8 \\
8 \\
8\end{array}$} & Prometryn & 2.07 & 48.5 & 1496.0 & 1.97 & 22.8 & 1490.2 \\
\hline & Bentazon & 2.30 & 47.3 & 1797.3 & 2.20 & 25.0 & 1797.5 \\
\hline & Prometryn + H.H & 2.45 & 51.6 & 1749.5 & 2.35 & 22.3 & 1748.3 \\
\hline & Bentazon + H.H & 2.53 & 50.6 & 1661.8 & 2.43 & 22.0 & 1659.5 \\
\hline & H.H. twice & 2.88 & 54.7 & 1629.3 & 2.78 & 28.2 & 1626.2 \\
\hline & Untreated & 1.77 & 47.2 & 1607.3 & 1.67 & 17.7 & 1603.7 \\
\hline \multicolumn{2}{|r|}{ L.S.D. at $5 \%$} & 0.21 & 0.21 & 12.28 & 0.21 & 4.93 & 16.20 \\
\hline
\end{tabular}

/plant and water consumptive use in both seasons, oil \% in the first season and seed yield/ plant in the second season. Using hand hoeing twice, prometryn treatment followed by hand hoeing once and bentazon treatment followed by hand hoeing once gave the highest values of all above characteristics under irrigation at $100 \%$ of FC water regime, compared to the same weed control treatments with irrigation at 60 and $80 \%$ of FC water regimes.

3.9.3. Effect of the interaction between cultivars and weed control treatments

Results in Table (14) show that all interactions between cultivars and weed control treatments had no significant effect for all characteristics under study, except for the number of branches/plant, oil $\%$ and water consumptive use in both seasons, broad leaved

Table (14): Effect of the interaction between cultivars and weed control treatments on weeds and some sesame studied traits in 2012and 2013 summer seasons.

\begin{tabular}{|c|c|c|c|c|c|c|c|c|}
\hline \multirow{2}{*}{\multicolumn{2}{|c|}{ Treatments }} & $\begin{array}{c}\text { Broad } \\
\text { leaved } \\
\text { weeds } \\
\text { (gm) }\end{array}$ & $\begin{array}{c}\text { Total } \\
\text { weeds } \\
\text { (gm) }\end{array}$ & $\begin{array}{l}\text { Branches } \\
\text { / plant } \\
\text { (No) }\end{array}$ & $\begin{array}{c}\text { Capsule } \\
\text { length } \\
(\mathrm{cm})\end{array}$ & $\begin{array}{c}\text { Oil } \\
\%\end{array}$ & $\begin{array}{l}\text { Branches } \\
\text { / plant (No) }\end{array}$ & Oil \% \\
\hline & & \multicolumn{5}{|c|}{2012 season } & \multicolumn{2}{|c|}{2013 season } \\
\hline \multirow{6}{*}{ 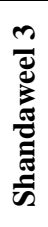 } & Prometryn & 346.0 & 438.3 & 1.58 & 3.44 & 48.4 & 1.69 & 49.3 \\
\hline & Bentazon & 15.0 & 210.3 & 1.68 & 3.51 & 47.7 & 1.79 & 49.4 \\
\hline & Prometryn + H.H & 15.8 & 54.4 & 1.94 & 3.54 & 51.3 & 2.06 & 51.4 \\
\hline & Bentazon + H.H & 15.2 & 50.0 & 1.99 & 3.78 & 51.2 & 2.10 & 51.1 \\
\hline & H.H. twice & 10.6 & 12.8 & 2.40 & 4.09 & 53.1 & 2.51 & 52.8 \\
\hline & Untreated & 467.7 & 677.0 & 1.43 & 3.27 & 47.2 & 1.53 & 49.8 \\
\hline \multirow{6}{*}{ 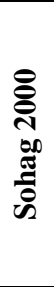 } & Prometryn & 384.8 & 477.0 & 2.70 & 3.26 & 48.3 & 2.81 & 51.5 \\
\hline & Bentazon & 29.9 & 230.3 & 2.98 & 3.50 & 48.2 & 3.09 & 48.7 \\
\hline & Prometryn + H.H & 21.3 & 58.8 & 3.48 & 3.98 & 51.0 & 3.59 & 48.6 \\
\hline & Bentazon + H.H & 14.8 & 37.0 & 3.60 & 3.68 & 50.4 & 3.71 & 53.7 \\
\hline & H.H. twice & 12.7 & 12.7 & 4.09 & 4.01 & 55.9 & 4.20 & 54.5 \\
\hline & Untreated & 563.0 & 780.1 & 2.30 & 3.08 & 45.9 & 2.41 & 50.9 \\
\hline & L.S.D. at $5 \%$ & 41.26 & 44.48 & 0.18 & 0.26 & 0.17 & 0.17 & 1.06 \\
\hline
\end{tabular}


and total weeds in the first season. The effects of interaction between Sohag-2000 cultivar with hand hoeing twice, prometryn treatment followed by hand hoeing once and bentazon followed by hand hoeing once were the best than comparable treatments with Shandaweel-3. This may be owing to effect of the interaction between the cultivars with mechanical and chemical methods in controlling weeds in sesame or genetic potential of sesame Sohag
2000 cultivar.

3.9. 4. Effect of the interaction between water regimes, cultivars and weed control treatments

Results in Table (15) reveal that the effects of the interaction between water regimes, cultivars and weed control treatments were significant only on water consumptive use in both seasons at 0.05 levels.

Yield reduction at $60 \%$ of $\mathrm{FC}$ water regime

Table (15):Effect of the interactions among water regimes, cultivars and weed control treatments on water consumptive use (CU) in 2012 and 2013 two summer seasons.

\begin{tabular}{|c|c|c|c|c|}
\hline \multicolumn{3}{|c|}{ Treatments } & \multirow{2}{*}{$\begin{array}{c}\begin{array}{c}\mathrm{CU} \\
\left(\mathrm{m}^{3} / \mathrm{fed} .\right)\end{array} \\
2012 \text { season }\end{array}$} & \multirow{2}{*}{$\begin{array}{c}\begin{array}{c}\text { CU } \\
\left(\mathrm{m}^{3} / \text { fed. }\right)\end{array} \\
2013 \text { season }\end{array}$} \\
\hline $\begin{array}{c}\text { Water } \\
\text { regimes }\end{array}$ & Cultivars & $\begin{array}{c}\text { Weed control } \\
\text { treatments }\end{array}$ & & \\
\hline \multirow{12}{*}{ 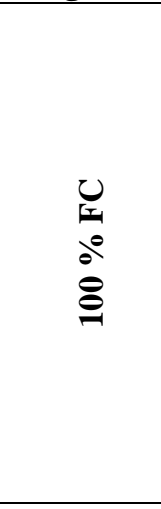 } & \multirow{6}{*}{ 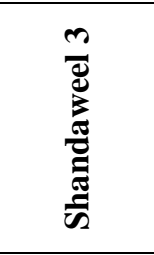 } & Prometryn & 2180.3 & 2173.0 \\
\hline & & Bentazon & 2220.7 & 2212.0 \\
\hline & & Prometryn + H.H & 2283.0 & 2273.3 \\
\hline & & Bentazon + H.H & 2287.3 & 2277.7 \\
\hline & & H.H. twice & 2371.7 & 2360.7 \\
\hline & & Untreated & 2087.0 & 2081.3 \\
\hline & \multirow{6}{*}{ 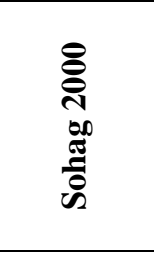 } & Prometryn & 2220.7 & 2212.0 \\
\hline & & Bentazon & 2291.7 & 2282.3 \\
\hline & & Prometryn + H.H & 2332.0 & 2321.3 \\
\hline & & Bentazon + H.H & 2380.7 & 2369.7 \\
\hline & & H.H. twice & 2421.0 & 2408.7 \\
\hline & & Untreated & 2059.0 & 2064.7 \\
\hline \multirow{12}{*}{$\begin{array}{l}0 \\
0 \\
0 \\
0 \\
\infty\end{array}$} & \multirow{6}{*}{ 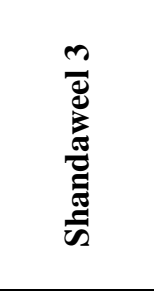 } & Prometryn & 1876.0 & 1877.3 \\
\hline & & Bentazon & 1937.0 & 1940.0 \\
\hline & & Prometryn + H.H & 2050.7 & 2056.0 \\
\hline & & Bentazon + H.H & 2098.7 & 2104.7 \\
\hline & & H.H. twice & 2116.0 & 2122.7 \\
\hline & & Untreated & 1828.0 & 1828.7 \\
\hline & \multirow{6}{*}{ 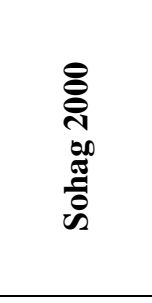 } & Prometryn & 1981.0 & 1984.3 \\
\hline & & Bentazon & 1998.3 & 2002.3 \\
\hline & & Prometryn + H.H & 2077.0 & 2082.3 \\
\hline & & Bentazon + H.H & 2124.7 & 2131.3 \\
\hline & & H.H. twice & 2173.0 & 2180.3 \\
\hline & & Untreated & 1932.7 & 1935.3 \\
\hline \multirow{12}{*}{$\begin{array}{l}U_{1} \\
0 \\
8 \\
8\end{array}$} & \multirow{6}{*}{ 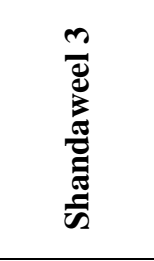 } & Prometryn & 1592.3 & 1588.0 \\
\hline & & Bentazon & 1614.0 & 1610.7 \\
\hline & & Prometryn + H.H & 1631.3 & 1628.3 \\
\hline & & Bentazon + H.H & 1736.3 & 1735.0 \\
\hline & & H.H. twice & 1758.0 & 1757.3 \\
\hline & & Untreated & 1448.0 & 1441.3 \\
\hline & \multirow{6}{*}{ 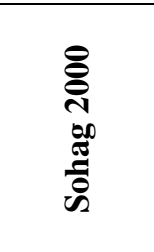 } & Prometryn & 1622.3 & 1619.3 \\
\hline & & Bentazon & 1644.7 & 1641.7 \\
\hline & & Prometryn + H.H & 1692.3 & 1690.7 \\
\hline & & Bentazon + H.H & 1762.7 & 1761.7 \\
\hline & & H.H. twice & 1836.7 & 1837.7 \\
\hline & & Untreated & 1544.0 & 1539.0 \\
\hline \multicolumn{3}{|c|}{ L.S.D. at $\mathbf{5 \%}$} & $\mathbf{1 7 . 3 6}$ & 22.90 \\
\hline
\end{tabular}


was higher than at $100 \%$ of $\mathrm{FC}$ water regime. This may be due to vigorous of plant growth under water sufficient on competition of weeds and decreasing this vigorous at low level of water regime. Sohag-2000 cultivar was the highest in seed yield and water use efficiency compared to Shandaweel 3 cultivar.

\section{CONCLUSION}

Under the conditions of the present investigation, using hand hoeing twice, bentazon followed by H.H. once, prometryn followed by H.H. once with Sohag-2000 cultivar and irrigation at $80 \%$ of FC which can be recommended as the best treatment for cultivating sesame under similar conditions of Sohag governorate, Egypt.

\section{REFERENCES}

A.O.A.C. (1990) Official Methods of Analysis Association of Official Analytical Chemists. $15^{\text {th }}$ Ed., Washington D.C., USA.

Abdel-Wahab A.M., Awad A., Abdel-Mottaleb H.M., Yousef M.S.H.A. and Abdel-Laltief E.E.A. (2005). The response of two sesame varieties to irrigation regimes and fertilization under surface and drip irrigation systems: 2Yield, yield components and WUF. The $11^{\text {th }}$ Conference of Agronomy, Fac. Agric., Assiut, Univ., pp 15-16.

Abo-El-Wafa A.M. and Abdel-Laltief E.A. (2006). Response of some sesame (Sesamum indicum L.). cultivars to fertilization treatments by micronutrient, biofertilizer and humix. Assiut. J. Agric. Sci., 37(1): 55-65.

Ahmed M. El- N., Mahmoud F. A. and Khalid A. I. (2010). Effect of irrigation and cultivar on seed yield, yield's components and harvest index of sesame ( Sesamum indicum L .). Res. J. Agric. and Biol. Sci., 6(4): 492-497.

Aysamy, M. and Kulandiavelu R. (1992). Effect of methods and intervals of irrigations on growth of sesame (Sesamum indicum L). Madras Agric. J., 79 (2): 104-104.

Attia, M.M.; Osman A.M.; Sayed M.A. and EL-Kafoury A. (1999). Effect of irrigation intervals and row width on yield, water use efficiency and some economic studies on sesame (Sesamum indicum L.) in calcareous soil. The Third Conference of On-Farm Irrigation and Agroclimatology, January 25-27, Dokki, Egypt.

Balyan R.S. (1993). Integrated weed management in oilseed crops in India. Proc. Int. Symp.,Indian Soc. Weed Sci , 1: 317-323
Basha H.A. (1998). Response of some sesame varieties to different row and hill spacing in newly cultivated sandy soil. Zagazig J. Agric. Res., 25 (3): 385-397.

Basha H.A. and Awaad H.A. (2000). Effect of harvesting date on three sesame varieties under newly cultivated sandy soil conditions. Zagazig J. Agric. Res., 27 (1): 31-41.

Bennett, M.; Katherine and Code B. (2003). Sesame recomendations for the Northern Territory. Agnote, 657(C22):1- 4.

Bulletin of the Agricultural Statistics. Part (2) Summer \& Nile crops 2012/ 2013, October 2014.

Damdar R.R., Bhale V.M., Wanjare P.G. and Deshmukh K.M. (2014). Effect of irrigation and nitrogen levels on yield and water use efficiency of summer sesame. AmericanEurasian J. Agric. \& Environ. Sci., 14 (9): 807-810.

Freed R, Einensmith S.P, Gutez S, Reicosky D, Smail VW, Wolberg P. (1989). User's Guide to MSTAT-C: A Software Program for the Design, Management and Analysis of Agronomic Research Experiments Michigan State University, East Lansing, ML, USA.

Gomez, K.A. and Gomez A.A. (1984). Split plot design analysis. In: Statistical procedures for agricultural research. 2nd Ed., John Willey and Sons, New York, USA.

Gurnah A. M. (1974). Critical weed competition periods in annual crops .Proc.5th East Africa, Weed control Conference, Nairobi Univ, Nairobi, Kenya, 88-98.

Hong Y., Yu J. M. and Chai K.C. (1985). Effect of drought stress on major upland crops. Res. Rep. of the Rural Development Administration Crop, Korea Republic ( C.F. Computer Res.) Intl. Agric. Cent. Inform. Serv., 27: 148- 155.

Hassanzadeh M., Ebadi A., Panahyan-e-Kivi M., Jamaati-e-Somarin Sh., Saeidi M. and Gholipouri A. (2009). Investigation of water stress on yield and yield components of sesame (Sesamum indicum L.) in Moghan. Reg. Res. J. Environ. Sci., 3(2): 239-244.

Israelsen O.W. and Hansen V.E. (1962). Irrigation principles and practices. $3^{\text {rd }}$ John Wiley and Sons Inc., New York, USA.

James G. Larry (1988). Principles of farm irrigation design, John Willey and Sons Publishers, United Kingdom.

Jensen M.E. (1983). Design and operation of farm irrigation systems. Amer. Soc. Agric. 
Eng., Michigan, U.S.A.

Joshi P. (1985). Sesame production in Rajasthan - constraints and opportunities. In: Srivastava, H.C., Bhaskaran, S., Vatsya, B., Menon, K.K.G. (Eds.), Oilseed Production Constraints and Opportunities. New Delhi, India pp. 199-204.

Kassab O.M., Mehanna H.M. and Aboelill A. (2012). Drought impact on growth and yield of some sesame varieties. J. Appl. Sci. Res., 8(8): 4544-4551.

Kwan K.S., Park S.H. and Jenks M.A. (2007). Changes in leaf cuticular waxes of sesame (Sesamum indicum L.) plants exposed to water deficit. J. Plant Physiol., 164: 11341143.

Metwally M.A.,Seif El-Yazal M.A.and Mahrous F.N. (1984). Effect of irrigation regimes and nitrogen fertilizer on sesame. Egypt. J. Soil Sci. 24:129-136.
Ministry of Irrigation. (1972). Water Investigation Section "Report on water requirements". Vol. 1 (in Arabic).

Rehab, H. KH. A. and Fakkar A. A. O. (2007). Response of two sesame varieties to nitrogen fertilizer and some weed control treatments. J. Agric. Sci. Mansoura Univ. 33 (1): 1 -16.

Singh D., Dagar J.C. and Gangwar B. (1992). Infestation by weeds and their management in oilseed crops: a review. Agric. Rev. 13, 163-175.

Ucan K., Killi F., Gencoglan C. and Merdun H. (2007). Effect of irrigation frequency and amount on water use efficiency and yield of sesame (Sesamum indicum, L.) under field conditions. Field Crops Res., 101: 249-258.

$$
\begin{aligned}
& \text { تأثير نظم الرى و معاملات مقاومة الحشائش على محصول السمسم } \\
& \text { عبده عبيد احمد إسماعيل ـ فنجرى شحات صديق " ـ صابر أبو الحمد محمود على"* } \\
& \text { المعمل المركزي لبحوث الحشائش ـ * معهد بحوث المحاصيل الحقلية ـ **معهد بحوث الأر اضى و المياه } \\
& \text { مركز البحوث الزر اعية ـ الجيزة - مصر }
\end{aligned}
$$

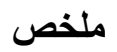

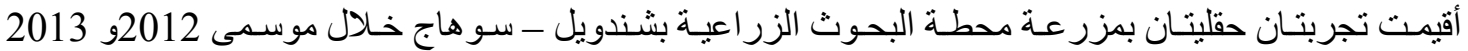

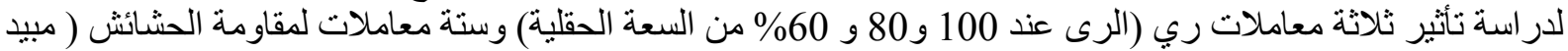

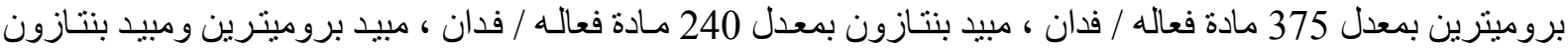

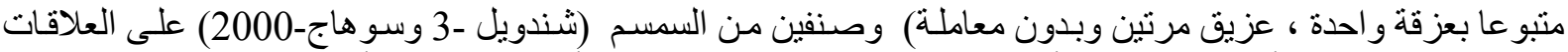

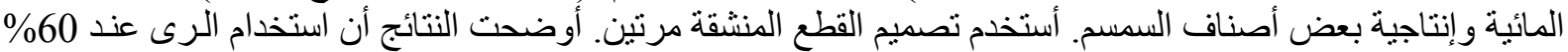

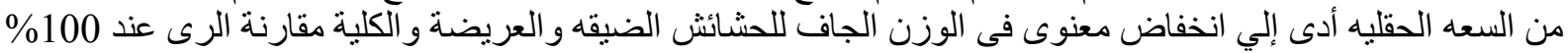

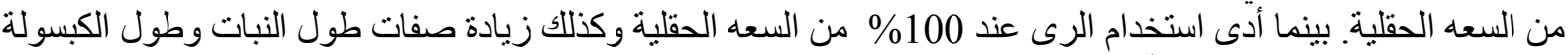

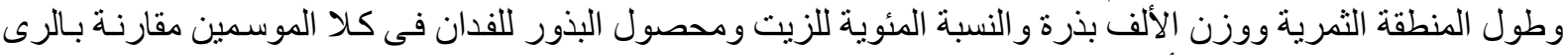

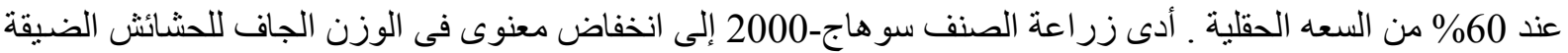

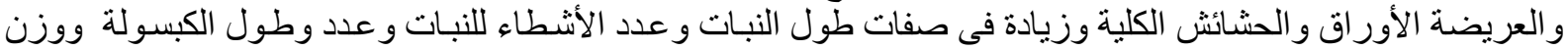

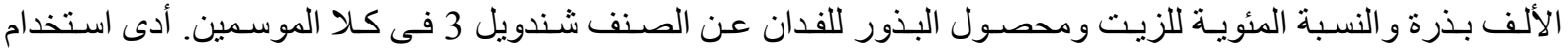

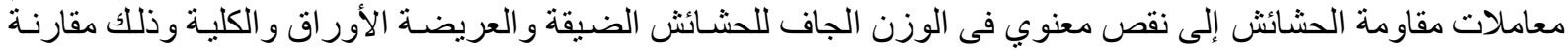

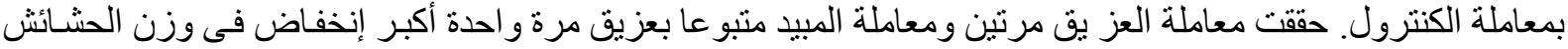

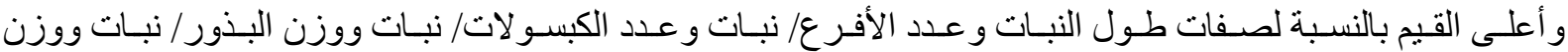

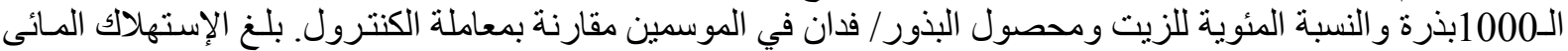

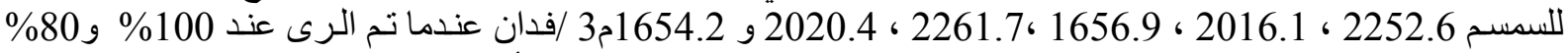

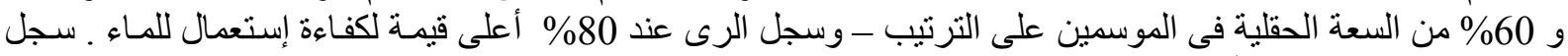

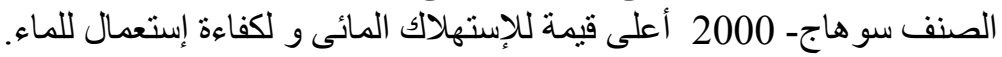

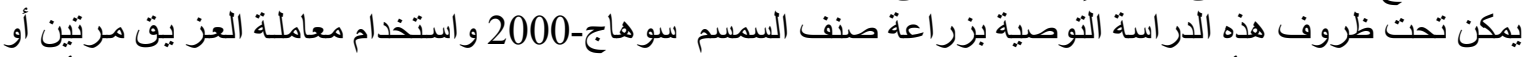

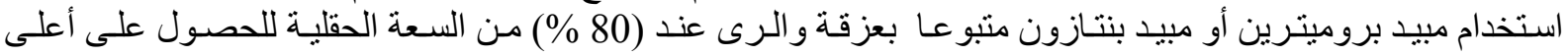
محصول من الزيت و السمسم لكل فدان. 